\title{
TINDAKAN HUKUM PENGGUNAAN PONSEL PADA OJEK ONLINE SAAT BERKENDARA
}

\author{
Arikha Saputra \\ Fakultas Hukum, Universitas Stikubank (Unisbank) Semarang \\ E-mail : arikhasaputra@edu.unisbank.ac.id
}

\begin{abstract}
ABSTRAK
Pada era saat ini transportasi merupakan sarana yang umum yang digunakan untuk mengangkut barang atau manusia dari satu tempat ke tempat lain. Transportasi dinilai dianggap telah menjadi kebutuhan yang pokok bagi setiap manusia untuk melakukan berbagai aktivitas sehari-hari misalnya bekerja atau sebagai penunjang usaha sehingga bisa dikatakan bahwa transportasi di era sekarang telah menjadi jantung dalam setiap kegiatan yang dilakukan oleh manusia. Transportasi darat yang dahulu melakukan kegiatannya di tempat-tempat tertentu namun di era milenia sekarang telah menjamur dan mulai digemari atau digandrungi oleh masyarakat umum yaitu transportasi darat berbasis online sehingga memunculkan aktivitas penggunaan ponsel atau alat telekomunikasi yang digunakan oleh pengangkut dalam hal ini transportasi online.

Penelitian ini merupakan suatu penelitian hukum dengan mempergunakan cara pendekatan yuridis sosiologis. Spesifikasi penelitian ini adalah deskriptif analitis, karena penelitian ini dapat memberikan gambaran serta analisis, yang menyeluruh dengan secara sistematis mengenai kenyataan yang ada di lapangan khususnya mengenai tentang pengaturan penggunaan ponsel saat berkendara yang terdapat di dalam perundang-undangan. Pengumpulan data dilakukan dengan cara melakukan observasi dan wawancara serta dengan menggunakan perundang-undangan yang berlaku.
\end{abstract}

Pengguna ponsel berbasis aplikasi dipermudah dengan adanya layanan cepat pemesanan moda transportasi online yang disebut ojek online yang berbasis aplikasi. Dengan melakukan pemesanan secara online maka secara otomatos akan timbul suatu perjanjian online diantara kedua belah pihak antara pengemudi dan pengguna atau penumpang.Perjanjian dalam ojek online tertera atau muncul dalam ponsel penumpang dan pengemudi sebagai transaksi perjalanan yang telah di sepakati keduanya. Transaksi elektonik dalam perjalanan ojek online merupakan perjanjian yang saling melekat kepada kedua belah pihak dalam suatu kegiatan pengangkutan. Dengan melakukan pemesanan secara online maka secara otomatis akan timbul suatu perjanjian online diantara kedua belah pihak antara pengemudi dan pengguna atau penumpang.

Perjanjian dalam ojek online tertera atau muncul dalam ponsel penumpang dan pengemudi sebagai transaksi perjalanan yang telah di sepakati keduanya. Transaksi elektonik dalam perjalanan ojek online merupakan perjanjian yang saling melekat kepada kedua belah pihak dalam suatu kegiatan pengangkutan. Pelarangan penggunaan handphone atau ponsel di jalan raya saat berkendara sebagaimana yang tercantum dalam perundang-undangan yakni Undang-Undang Nomor 22 Tahun 2009 tentang Lalu Lintas dan Angkutan Jalan yang tercantum dalam pasal 106 ayat (1) yang menyebutkan bahwa "setiap orang yang mengemudikan kendaraan bermotor di jalan wajib mengemudikan kendaraannya dengan wajar dan penuh konsentrasi" sehingga memunculkan kebijakan atau tindakan hukum yang dilakukan oleh pihak kepolisian ialah dengan menerapkan cara 3E yaitu : Enginering, Education dan Enforcement. 
Kata Kunci : Transportasi Online, Tindakan Hukum, UULAJ

\section{ABSTRACT}

In the current era, transportation is a common means used to transport goods or people from one place to another. Transportation is considered considered to have become a basic need for every human being to carry out various daily activities such as work or as a business support so that it can be said that transportation in the present era has become the heart in every activity carried out by humans. Land transportation which used to carry out its activities in certain places, but in the millennium has now mushroomed and began to be favored or loved by the general public, namely online based land transportation so as to bring up the use of cellphones or telecommunications equipment used by transporters in this case online transportation.

This research is a legal research using a sociological juridical approach. The specification of this study is descriptive analytical, because this study can provide an overview and analysis, which is thoroughly systematically regarding the reality in the field, especially regarding the regulation of cellphone use while driving contained in legislation. Data collection is done by conducting observations and interviews and by using applicable legislation.

Application-based mobile users are facilitated by the existence of fast online booking mode services called application-based online motorcycle taxis. By making an online order automatically an online agreement will arise between the two parties between the driver and user or passenger. The agreement in the online motorcycle taxi is displayed or appears on the passenger and driver's cellphone as a travel transaction that has been agreed by both. Electronic transactions in online motorcycle taxi trips are agreements that are inherent to both parties in a transportation activity. By ordering online, an online agreement will arise automatically between the two parties between the driver and the user or passenger.

An online motorcycle taxi agreement is printed or appears on the passenger and driver's cellphone as a travel transaction agreed upon by both. Electronic transactions in online motorcycle taxi trips are agreements that are inherent to both parties in a transportation activity. Prohibition of using cellphones or cellphones on the road while driving as stated in the legislation, namely Law Number 22 Year 2009 concerning Road Traffic and Transportation stated in article 106 paragraph (1) which states that "every person driving a motorized vehicle on the road must drive the vehicle properly and full of concentration "so that the emergence of policies or legal actions taken by the police is to apply the 3E method, namely: Engineering, Education and Enforcement.

Keywords: Online Transportation, Legal Action, UULAJ

\section{Pendahuluan}

Pada era saat ini transportasi merupakan sarana yang umum yang digunakan untuk mengangkut barang atau manusia dari satu tempat ke tempat lain. Transportasi dinilai dianggap telah menjadi kebutuhan yang pokok bagi setiap manusia untuk melakukan berbagai aktivitas seharihari misalnya bekerja atau sebagai penunjang usaha sehingga bisa dikatakan bahwa transportasi di era sekarang telah menjadi jantung dalam setiap kegiatan yang dilakukan oleh manusia. Di era saat ini tidaklah susah dalam melakukan segala aktivitas yang bekaitan dengan sarana transportasi apalagi dengan munculnya transportasi berbasis online yang memudahkan penggunanya dapat mengakses transportasi dengan cepat tanpa mengalami kendala. Dengan demikian bahwa transportasi memiliki peranan 
yang sangat penting dari roda perekonomian serta kehidupan, maka lalu lintas dan angkutan jalan semestinya harus mengalami perubahan dalam tatanan sehingga mampu membentuk suatu sistem transportasi bertaraf nasional secara terpadu dan mampu memberikan solusi kemacetan di jalan raya serta mewujudkan ketersediaan transportasi yang aman, nyaman dan layak bagi penggunanya yang sesuai dengan tingkat kebutuhan lalu lintas dan pelayanan angkutan yang tertib, nyaman, cepat, lanncar dan berbiaya murah.

Transportasi darat yang dahulu melakukan kegiatannya di tempattempat tertentu namun di era milenia sekarang telah menjamur dan mulai digemari atau digandrungi oleh masyarakat umum yaitu transportasi darat berbasis online sehingga memunculkan mengenai karakteristik moda transportasi darat yang kita kenal dengan perbedaan mengenai kendaraan pribadi dan kendaraan umum. Dikatakan kendaraan pribadi dikarenakan kendaraan yang dioperasionalkan hanya untuk orang yg memiliki kendaraan tersebut sedangkan kendaraan umum adalah kendaraan yang disediakan untuk dipergunakan oleh masyarakat umum dengan dasar memungut biaya atau ongkos.

Zaman saat ini, terdapat fenomena ojek yang cukup menyita perhatian masyarakat dengan munculnya transportasi berbasis aplikasi yang dinilai sangat meringankan atau membantu masyarakat dalam memerlukan atau memenuhi kebutuhan serta dengan munculnya transportasi berbasis aplikasi ini menjawab permasalahan transportasi yang ada pada bangsa Indonesia. Transportasi berbasis aplikasi ini di era milenia sekarang telah menjadi primadona, hal ini dikarenakan dari pengoperasian pemesanan serta mengakses jasa transportasi dinilai memudahkan bagi para pengguna jasa transportasi. Hanya dengan menggunakan alat telekomunikasi yakni gadget yang telah dipasangi oleh aplikasi jasa trransportasi tersebut, kita dapat memperoleh kemudahan dalam hal bertransportasi yang nyaman dan lebih murah dari segi ongkos.

Fenomena yang muncul diatas menarik untuk ditelisik secara mendalam, hal ini dikarenakan transportasi online selain memiliki beberapa keunggulan atau kelebihan yang diharapkan mampu mengatasi persoalan dari pengguna jalan namun transportasi ini ternyata juga memiliki kelemahan atau kekurangan yg perlu dikaji lebih mendalam mulai dari penggunaan terknologi berbasis aplikasi, asuransi yang diberikan oleh pengangkut kepada penumpang apabila terjadi evenement serta penggunaan moda transportasi sepeda motor yang digunakan sebagai alat dari moda transportasi serta mata pencaharian dari pengangkut. Namun penulis lebih menarik untuk menelisik atau menggali tentang penggunaan ponsel atau alat telekomunikasi yang digunakan oleh pengangkut dalam hal ini transportasi online yang terkadang tidak sesuai dengan sebagai mana mestinya. Penulis menyadari hal ini tidak terlepas dari perkembangan zaman yang mengarah kepada canggihnya kemajuan teknologi maka perkembangan zaman pun semakin melesat maju dengan begitu cepatnya. Dengan demikian menimbulkan anggapan bahwa semakin maju dari zaman, maka teknologi pun akan semakin berkembang dan canggih. Namun hal yang perlu dihindari 
bahwa penggunaan ponsel atau alat telekomunikasi yang tidak sebagaimana mesti nya dirasa akan memunculkan rasa kecemburuan sosial kepada pengguna jalan atau pengemudi dari transportasi lain yang sama-sama menggunakan sepeda motor sebagai alat transportasi.

Hal ini dapat dilihat dengan maraknya penggunaan ponsel yang dilakukakan oleh pengemudi transportasi online yang dengan sengaja meletakkan alat telekomunikasi atau ponselnya di atas spedometer dari kendaraannya. Hal ini lah yang dapat menimbulkan rasa kecemburuan akan penggunaan ponsel, bahwa penggunaan ponsel sangatlah dilarang oleh pihak Kepolisian bagi pengguna kendaraan di jalan raya. Namun sangat disayangkan bahwa transportasi online ternyata menggunakan ponsel saat berkendara, dimana sering kali pengemudi melihat ponsel yang ditaruhnya pada kendaraan mereka yang berguna untuk mengecek panggilan orderan ataupun rute dari perjalanan yang mereka tuju. Penggunaan ponsel dalam berkendara dinilai sangatlah membahayakan baik bagi pengguna jalan lain maupun pengemudi yang mengendarai kendaraannya padahal larangan menggunakan ponsel atau alat telekomunikasi terkadang telah disosialisasikan oleh pihak Kepolisian dengan dasar ketentuan dari UndangUndang No 22 Tahun 2009 tentang Lalu Lintas dan Angkutan Jalan. Pengendara kendaraan bermotor yang menggunkan alat telekomunikasi atau ponsel dapat terkena pasal 106 ayat (1) yang berbunyi setiap orang yang mengemudikan kendaraan bermotor di Jalan wajib mengemudikan kendaraannya dengan wajar dan penuh konsentrasi.
Berdasarkan uraian dari latar belakang yang telah dikemukakan diatas, maka perumusan masalah yang timbul dalam penelitian adalah sebagai berikut : Bagaimana tindakan hukum penggunaan ponsel pada ojek online saat berkendara berdasarkan perundang-undangan?

\section{Metode Penelitian}

Penelitian tentang "Tindakan Hukum Penggunaan Ponsel Pada Ojek Online Saat Berkendara" ini merupakan suatu penelitian hukum dengan mempergunakan cara pendekatan yuridis sosiologis.

Penelitian ini menggunakan spesifikasi penelitian ini adalah deskriptif analitis, karena penelitian ini dapat memberikan gambaran serta analisis, yang menyeluruh dengan secara sistematis mengenai kenyataan yang ada di lapangan khususnya mengenai tentang pengaturan penggunaan ponsel saat berkendara yang terdapat di dalam perundangundangan.

Data yang dikumpulkan adalah data yang berhubungan dengan Peraturan Perundang-Undangan yang berlaku yakni Undang-Undang No 22 Tahun 2009 tentang Lalu Lintas Angkutan Jalan serta akan ditinjau pula dengan teori-teori di dalam hukum pengangkutan serta pengumpulan data dalam penelitian ini ditunjang dengan melakukan wawancara dan observasi.

\section{Pembahasan}

Transportasi berbasis online merupakan penggabungan dari segi jasa transportasi dan teknologi komunikasi. Transportasi berbasis aplikasi online juga dilengkapi dengan fitur Global Positioning System (GPS) sehingga penggunaan ponsel dalam transportasi online menjadi utama 
dikarenakan ponsel digunakan untuk melakukan tramsaksi dan sekaligus untuk memberikan informasi keberadaan pengemudi dan pengguna dengan rute terdekat. Sehingga sering kali pengemudi menggunakan ponsel saat berkendara. Sering kali terlihat pengemudi transportasi darat online menaruh ponsel di atas speedometer atau spion di kendaraannya. Peletakan ponsel pada speedometer atau spion sering dijumpai ketika pengemudi berkendara di jalan raya. Hal ini jelas sangatlah membahayakan baik penumpang dan pengemudi karena dapat mengakibatkan kecelakaan. Dengan meletakkan ponsel di depan maka dapat membuat pengemudi sering kali melihat ponsel yang berada di depannya sehingga hal ini dapat saja mengakibatkan hilangnya konsentrasi dari pengemudi ojek online yang dapat berakibat fatal terjadinya kecelakaan di jalan raya.

Fenomena diatas yang muncul merupakan hasil dari modernisasi zaman di era saat ini. Fenomena yang terjadi merupakan fenomena dari perkembangan terkait antara transportasi dan telekomunikasi. Perkembangan dari keduanya tidak lepas dari peran perkembangan ilmu pengetahuan (sains) dan teknologi serta inovasi. Salah satu perkembangan teknologi dan inovasi yakni terciptanya aplikasi yang dapat menghubungkan pengguna dengan moda transportasi darat online yang saat ini diminati oleh masyarakat. Pengguna ponsel berbasis aplikasi dipermudah dengan adanya layanan cepat pemesanan moda transportasi online yang disebut ojek online yang berbasis aplikasi. Dengan menggunakan aplikasi ojek online, maka pengguna transportasi tidak perlu kesulitan dalam mencari transportasi ojek hanya dengan melakukan proses apply pengguna mendapatkan kemudahan dalam melakukan aktivitas bepergian. Dengan melakukan pemesanan secara online maka secara otomatis akan timbul suatu perjanjian online diantara kedua belah pihak antara pengemudi dan pengguna atau penumpang.

Perjanjian dalam ojek online tertera atau muncul dalam ponsel penumpang dan pengemudi sebagai transaksi perjalanan yang telah di sepakati keduanya. Transaksi elektonik dalam perjalanan ojek online merupakan perjanjian yang saling melekat kepada kedua belah pihak dalam suatu kegiatan pengangkutan. Menurut Undang-Undang Republik Indonesia No.11 tahun 2008 tentang Informasi dan Transaksi Elekronik (UU ITE) menyebutkan bahwa transaksi elektronik adalah perbuatan hukum yang dilakukan menggunakan komputer, jaringan komputer, dan/atau media elektronik lainnya. Media elektonik yang digunakan dalam bertransaksi online dalam perjalanan antara kedua belah pihak adalah ponsel. Transaksi perjalanan yang tertera di dalam ponsel merupakan hasil dari kesepakatan antar kedua belah pihak, yang memunculkan hak dan kewajiban diantara keduanya.

Kewajiban yang timbul dari transaksi elektronik dari pengemudi adalah memiliki kewajiban dengan memulai dari titik penjemputan awal sampai dengan titik akhir seperti yang tertera dalam ponsel dengan dasar keselamatan dan pengemudi mempunyai hak untuk mendapatkan royalty atau upah dari setiap perjalanan yang telah disepakati dalam transaksi elektronik. Adapun kewajiban dari penumpang ialah membayar ongkos sesuai dengan tarif yang telah tertera di ponsel sesuai 
dengan transaksi atau perjanjian online dan penumpang dalam hal ini mendapatkan hak istimewa yakni sampai di tempat tujuan dengan selamat, aman dan nyaman dari pengemudi ojek online tersebut. Kedua belah pihak saling bersepakat dan mematuhi dengan segala yang muncul dalam program aplikasi pemesanan dari layanan transportasi darat online.

Perjanjian yang terdapat dalam perjanjian antara pengemudi online dan penumpang tercantum dalam aplikasi handphone atau ponsel merupakan hasil dari kesepakatan sebagaimana yang sesuai dengan konsep dari perjanjian bahwa para pihak yang mengadakan suatu perjanjian harus bersepakat, setuju mengenai hal yang menjadi pokok dari perjanjian yang akan diadakan, apa yang dikehendaki oleh pihak satu, juga dikehendaki oleh pihak lain. Hal ini juga sejalan dengan definisi dari pengangkutan yakni perjanjian timbal balik antara pengangkut dengan pengirim dan/atau penumpang, dimana pengangkut mengikatkan diri untuk menyelenggarakan pengangkutan barang dan/atau orang dari suatu tempat ke tempat tujuan tertentu dengan selamat, sedangkan pengirim dan/atau penumpang mengikatkan diri untuk membayar membayar angkutan. Dengan demikan dapat dikatakan bahwa sifat dari perjanjian ialah terikat antara satu dengan yang lain.

Pengangkutan darat online merupakan pengangkutan yang menerapkan pelaksanan perjanjian melalui transaksi online dengan memanfaatkan penggunaan ponsel sebagai media atau sarana penghubung antara pengemudi dan penumpang. Oleh karena itu tidaklah heran bahwa penggunaan ponsel menjadi salah satu aktivitas yang dilakukan oleh pengemudi online dalam hal melaksanakan pekerjaannya.

Pelarangan penggunaan handphone atau ponsel di jalan raya saat berkendara sebagaimana yang tercantum dalam perundangundangan yakni Undang-Undang Nomor 22 Tahun 2009 tentang Lalu Lintas dan Angkutan Jalan yang tercantum dalam pasal 106 ayat (1) yang menyebutkan bahwa "setiap orang yang mengemudikan kendaraan bermotor di jalan wajib mengemudikan kendaraannya dengan wajar dan penuh konsentrasi.

Larangan penggunaan ponsel ketika berkendara dapat mengganggu konsentrasi bagi pengemudi kendaraan bermotor, hal ini bertujuan memberikan perlindungan dan jaminan keselamatan berlalulintas kepada setiap orang. Oleh karena itu, pihak kepolisian berkomitmen untuk konsen dalam hal pencegahan penggunaan ponsel saat berkendara dengan memberikan edukasi atau informasi terhadap pengguna kendaraan bermotor akan bahaya penggunaan ponsel di jalan raya. Hal ini dikarenakan penggunaan ponsel di jalan raya merupakan salah satu faktor dari dampak terjadinya kecelakaan di jalan raya. Namun masih banyak pengguna kendaraan bermotor sering kali masih melakukan pelanggaran terkait penggunaan ponsel saat berkendara, hal ini dikarenakan kurangnya kesadaran dan ketaatan hukum dari pengguna kendaraan bahwa dengan menggunakan ponsel saat berkendara dapat menimbulkan kerugiaan bagi dirinya dan orang lain.

$$
\text { Fungsi kepolisian yang }
$$

berkaitan tentang tugas dan kewenangan pihak kepolisian secara umum yakni kegiatan pekerjaan yang dilaksanakan oleh pihak kepolisian 
yang meliputi dari kegiatan pencegahan (prventif) dan penegakan hukum (represif). Polisi lalu lintas merupakan unsur pelaksana yang bertugas untuk menyelenggakan tugas kepolisian yang mencakup penjagaan, pengaturan, pengawalan dan patrol, serta memberikan pendidikan kepada masyarakat dan dapat melakukan rekayasa lalu lintas, registrasi dan identifikasi pengemudi atau kendaraan bermotor, penyidikan kecelakaan lalu lintas dan melakukan penegakan hukum yang bertujuan untuk menjaga keamanan, kelancaran dan ketertiban dalam berlalu lintas.

Berdasarkan kewenangan yang diberikan oleh pihak kepolisian dapat melakukan tindakan hukum dalam hal pencegahan maupun penanganan dari penggunaan ponsel saat berkendara, hal ini dikategorikan sebagai pelanggaran berlalu lintas dikarenakan menggunakan alat hubung yang dapat mengakibatkan hilangnya konsentrasi dalam berkendara di jalan raya. Hal ini sebagaimana yang tercantum dalam pasal 106 ayat (1) yang menyebutkan bahwa "setiap orang yang mengemudikan kendaraan bermotor di jalan wajib mengemudikan kendaraannya dengan wajar dan penuh konsentrasi. Pelanggaran yang dilakukan oleh pengemudi dapat dikenakan sanksi sesuai dengan perundang-undangan yang berlaku yakni Undang-Undang Nomor 22 Tahun 2009 tentang Lalu Lintas dan Angkutan Jalan yang termuat dalam pasal 283 dengan sanksi berupa denda maksimal Rp. 750.000 serta kurungan 3 (tiga) bulan.

Penggunaan ponsel saat berkendara bahwa yang merupakan pelanggaran yakni pengemudi yang dengan sengaja melakukan pengoperasian suatu alat komunikasi dengan menggunakan panca indera yang dinilai dapat menganggu aktivitas berkendara sehingga dapat menghilangkan konsentrasi dari pengemudi dalam mengendarai kendaraannya di jalan raya. Sehingga yang menjadi indikator seseorang melakukan pelanggaran di jalan raya khususnya penggunaan ponsel adalah pengemudi yang melakukan pengoperasiaan alat telekomunikasi saat berkendara dengan menggunakan panca indera. Pihak kepolisian selaku pihak pelaksana dalam penyelenggaraan lalu lintas senantiasa memberikan edukasi dan sosialisasi terhadap masyarakat tentang pentingnya menjaga keselamatan sehingga menciptakan ketertiban di jalan raya dengan tidak melakukan pelanggaran-pelanggaran yang dilarang dalam lalu lintas.

Tindakan hukum yang dilakukan oleh pihak kepolisian ialah dengan menerapkan cara $3 \mathrm{E}$ yaitu : Enginering, Education dan Enforcement. Penerapan cara pertama dengan Engineering yakni dengan melakukan komunikasi terkait pembuatan alat atau benda yang dapat membantu dalam hal pencegahan atau penanganan lalu lintas, sehingga dalam penerapan dengan menggunakan cara Enginering ini memunculkan kerjasama dengan pihak lain atau produsen yang terkait dengan pembuatan kendaraan bermotor, penerapan cara kedua ialah education yakni dengan melakukan pemberian pendidikan dan sosialisasi kepada masyarakat tentang pentingnya keamanan dan keselamatan dalam berlalu lintas. Penerapan dengan cara education sering dilakukan oleh pihak kepolisian, hal ini dikarenakan dapat memberikan pengetahuan kepada masyarakat tentang keselamatan 
berkendara di jalan raya. Penerapan cara ketiga yang dilakukan oleh kepolisian ialah enforcement yakni dengan melakukan penindakan hukum saat terjadinya pelanggaran lalu lintas. Penindakan hukum merupakan tindakan yang diambil oleh pihak kepolisian saat bertugas di jalan raya. Penindakan yang dilakukan bertujuan untuk memberikan efek dari kesalahan yang dilakukan oleh pengemudi sehingga dikemudian hari tidak terulang kembali kesalahan atau pelanggaran yang dilakukannya agar terciptanya masyarakat tertib, taat akan peraturan dan sadar hukum. Pihak kepolisian selalu melakukan koordinasi dengan pihak-pihak yang terkait dalam upaya pencegahan kecelakaan di jalan raya dengan membuat kebijakan dan pengkajian secara menyeluruh terhadap penyebab dari kecelakaan tersebut. Oleh karena itu, penangangan dalam hal lalu lintas yang bertujuan dalam pencegahan kecelakaan di jalan raya tidak hanya dapat diselesaikan oleh pihak kepolisian namun semua unsur kepentingan dapat terlibat, seperti masyarakat, kepolisian dan lembaga lainnya sehingga terdapat sinergitas antara semuanya dalam menciptakan keselamatan dalam berkendara di jalan raya. Hal ini sebagaimana tercantum dalam pasal 226 UndangUndang Nomor 22 tahun 2009 tentang Lalu Lintas dan Angkutan Jalan yang menyebutkan mengenai upaya pencegahan kecelakaan lalu lintas dapat dilaksanakan melalui :

1. Partisipasi para pemangku kepentingan.

2. Pemberdayaan masyarakat.

3. Penegakan hukum.

4. Kemitraan global

Berdasarkan penerapan yang dilakukan pihak kepolisian dengan cara 3E, yakni Enginering, Education dan Enforcement menggambarkan bahwa pihak kepolisian konsen dengan pencegahan dan penanganan masalah penggunaan ponsel saat berkendara dengan melakukan tindakan hukum. Tindakan hukum dengan cara Enginering, Education merupakan langkah pengendalian atau tindakan yang masuk dalam kategori secara preventif. Tindakan preventif merupakan suatu tindakan pengendalian sosial yang dilakukan untuk mencegah atau mengurangi kemungkinan terjadinya hal-hal yang tidak diinginkan di masa mendatang. Tindakan preventif dinilai pula sebagai tindakan upaya penanganan atau tindakan pencegahan yang setidaknya berdampak untuk mengurangi dan mencegah kemungkinan yang terjadi. Sedangkan tindakan Enforcement masuk dalam tindakan pengendalian bersifat represif. Tindakan represif adalah suatu tindakan pengendalian sosial yang dilakukan setelah terjadinya suatu pelanggaran atau peristiwa buruk. Dari penjelasan pengertian preventif dan represif di atas, kita dapat mengetahui bahwa tujuan utumanya adalah sebagai pengendalian sosial. Adapun tujuan adalah sebagai berikut :

1. Dapat sebagai pencegahan atau pengurangan dari terjadinya pelanggaran

2. Menjaga keamanan, keselamatan dan ketertiban di masyarakat

3. Mewujudkan keadilan dan kenyamanan di dalam masyarakat

4. Menciptakan dan menegakkan hukum di masyarakat

5. Menciptakan kesadaran untuk pelaku terhadap pelanggaran yang dilakukan 


\section{Simpulan}

Tindakan hukum yang dilakukan oleh pihak kepolisian ialah dengan menerapkan cara 3E yaitu : Enginering, Education dan Enforcement Tindakan hukum dengan cara Enginering, Education merupakan langkah pengendalian atau tindakan yang masuk dalam kategori secara preventif. Sedangkan tindakan Enforcement masuk dalam tindakan pengendalian bersifat represif.

\section{Saran}

1. Perlu adanya sosialisasi secara berjangka kepada pengemudi ojek dan pengguna jalan raya tentang pelarangan penggunaan ponsel saat berkendara

2. Pihak kepolisian perlu memberikan sanksi tegas kepada para pengemudi ojek online atau pengguna kendaraan yang dengan sengaja mengoperasikan ponselnya saat berkendara

\section{Daftar Pustaka}

Abbas Salim, 2000, Manajemen Transportasi, PT. Raja Grafindo Persada, Jakarta

Abdulkadir Muhammad, 1998, Hukum Pengangkutan Niaga, Citra Aditya Bakti, Bandung

Cholid Narbuko dan Abu Achmadi, 2001, Metodologi Penelitian, Bumi Aksara, Jakarta

Christine Kansil, 2013, Pokok-Pokok Pengetahuan Hukum Dagang Indonesia, Sinar Grafika, Jakarta Timur

C.S.T. Kansil, 2006, Modul Hukum Perdata Termasuk Asas-Asas Hukum Perdata, PT. Pradnya Paramita, Jakarta

Hasyim, Farida, 2009, Hukum Dagang, Sinar Grafika, Jakarta
H.M.N. Purwosutjipto,1984, Pengertian Pokok Hukum Dagang Indonesia Jilid 3 Hukum Pengangkutan, Djambatan, Jakarta

H. Salim HS, 2005, Perkembangan Hukum Kontrak Innominaat diIndonesia, Cet. III, Sinar Grafika, Jakarta

J.S.Badudu dan Sutan Mohammad, 1994, Kamus Umum Bahasa Indonesia, PT. Integraphic, Jakarta,

Muchtaruddin Siregar, 1990, Beberapa Masalah Ekonomi dan Manajemen Pengangkutan, Lembaga Penerbit FE UI, Jakarta

Satjipto Rahardjo, 1996, Ilmu Hukum, Cet IV, PT Citra Aditya, Bandung

Soerjono Soekanto, 1984, Pengantar Penelitian Hukum, Universitas Indonesia Press, Jakarta

Faktor Yang 1993, Faktor-
Penegakan Hukum, Raja Grafindo
Persada, Jakarta

Soerjono Soekanto dan Sri Sri Mamuji, 2006, Penelitian Hukum Normatif Suatu Tingkatan, Cet ke 9, Rajawali Press, Jakarta

Sution Usman Adji, Djoko Prakoso dan Hari Pramono, 1991, Hukum Pengangkutan-Indonesia, Rineka Cipta, Jakarta

Wijaya C,2009, Makalah Perencanaan Angkutan Umum, Sipil UI

Zainal Asikin, 2016, Hukum Dagang, Rajawali Pers, Jakarta

Rifusua, Agus Imam, 2010, Analisis Faktor-faktor Yang Mempengaruhi Permintaan Busway di DKI Jakarta Tahun 2004-2008. Tesis Fakultas Ekonomi Universitas Indonesia 